\title{
Modeling the influence of a reduced equator-to-pole sea surface temperature gradient on the distribution of water isotopes in the Early/Middle Eocene
}

\author{
Eveline N. Speelman ${ }^{\mathrm{a}, *}$, Jacob O. Sewall $^{\mathrm{b}}$, David Noone ${ }^{\mathrm{c}}$, Matthew Huber ${ }^{\mathrm{d}}$, Anna von der Heydt ${ }^{\mathrm{e}}$, \\ Jaap Sinninghe Damsté ${ }^{\mathrm{a}, \mathrm{f}}$, Gert-Jan Reichart ${ }^{\mathrm{a}, \mathrm{g}}$ \\ a Utrecht University, Faculty of Geosciences, Budapestlaan 4, 3584 CD Utrecht, The Netherlands \\ ${ }^{b}$ Kutztown University, Physical Sciences, Boehm Science Center 422, P.O. Box 730, Kutztown, PA 19530, USA \\ c University of Colorado at Boulder, Atmospheric and Oceanic Sciences, UCB 311, CO 80309-0311, USA \\ d Purdue University, Department of Earth and Atmospheric Sciences, West Lafayette, IN 47907, USA \\ e Utrecht University, Institute for Marine and Atmospheric Research (IMAU), Princetonplein 5, 3584 CC Utrecht, The Netherlands \\ ${ }^{f}$ NIOZ Royal Netherlands Institute for Sea Research, P.O. Box 5, 1790 AB Den Burg, The Netherlands \\ ${ }^{g}$ Alfred Wegener Institute for Polar and Marine Research, Am Handelshafen 12, D-27570, Bremerhaven, Germany
}

\section{A R T I C L E I N F O}

\section{Article history:}

Received 4 December 2009

Received in revised form 5 July 2010

Accepted 8 July 2010

Available online 10 August 2010

Editor: P. DeMenocal

\section{Keywords:}

hydrogen isotopes

climate modeling

hydrological cycling

paleoclimate

Eocene

Azolla

\begin{abstract}
A B S T R A C T
Proxy-based climate reconstructions suggest the existence of a strongly reduced equator-to-pole temperature gradient during the Azolla interval in the Early/Middle Eocene, compared to modern. Changes in the hydrological cycle, as a consequence of a reduced temperature gradient, are expected to be reflected in the isotopic composition of precipitation $\left(\delta \mathrm{D}, \delta^{18} \mathrm{O}\right)$. The interpretation of water isotopic records to quantitatively reconstruct past precipitation patterns is, however, hampered by a lack of detailed information on changes in their spatial and temporal distribution. Using the isotope-enabled version of the National Center for Atmospheric Research (NCAR) atmospheric general circulation model, Community Atmosphere Model v.3 (isoCAM3), relationships between water isotopes and past climates can be simulated. Here we examine the influence of an imposed reduced meridional sea surface temperature gradient on the spatial distribution of precipitation and its isotopic composition in an Early/Middle Eocene setting. As a result of the applied forcings, the Eocene simulation predicts the occurrence of less depleted high latitude precipitation, with $\delta \mathrm{D}$ values ranging only between 0 and $-140 \%$ (compared to Present-day 0 to $-300 \%$ ). Comparison with Early/Middle Eocene-age isotopic proxy data shows that the simulation accurately captures the main features of the spatial distribution of the isotopic composition of Early/Middle Eocene precipitation over land in conjunction with the aspects of the modeled Early/Middle Eocene climate. Hence, the included stable isotope module quantitatively supports the existence of a reduced meridional temperature gradient during this interval.
\end{abstract}

(c) 2010 Elsevier B.V. All rights reserved.

\section{Introduction}

The Early to Middle Eocene was one of the warmest intervals of the Cenozoic, with little or no polar terrestrial ice, global mean surface temperatures much warmer than present, deep sea temperatures $10{ }^{\circ} \mathrm{C}$ warmer than present (Sloan and Barron, 1992; Zachos et al., 1993, 1994; Sloan, 1994; Greenwood and Wing, 1995; Jahren and Sternberg, 2003), and atmospheric $\mathrm{pCO}_{2}$ in the range of 400 3500 ppm (Pearson and Palmer, 2000). During a 1.2 Myr period $49 \mathrm{Ma}$ ago, the free floating aquatic fern Azolla grew and reproduced in the Eocene Arctic (Brinkhuis et al., 2006; Speelman et al., 2009a), indicating that the surface waters of the Arctic Basin freshened considerably. During this so-called Azolla interval, tropical sea surface

\footnotetext{
* Corresponding author. Tel.: + 3130 2536722; fax: + 31302535302 E-mail address: e.speelman@geo.uu.nl (E.N. Speelman).
}

temperatures (SSTs) were somewhat warmer than today (with a mean annual temperature (MAT) of $32-34{ }^{\circ} \mathrm{C}$ at $19^{\circ} \mathrm{C}$ ) (Pearson et al., 2007), while Arctic SSTs were substantially higher (with a MAT of $\sim 10{ }^{\circ} \mathrm{C}$ ) (Brinkhuis et al., 2006). The consequently reduced temperature gradient between the equator and the poles and the presence of freshwater at the North Pole (Brinkhuis et al., 2006) provide important boundary conditions for understanding the hydrological cycle and latent heat transport during this interval. While earlier in the Eocene (from 55 to $50 \mathrm{Ma}$ ) temperature gradients may have been even lower (e.g. Pearson et al., 2007; Sluijs et al., 2008), data coverage in the Azolla interval centered near $49 \mathrm{Ma}$ is more complete and we thus focus on that interval.

The prevalence of a reduced equator-to-pole sea surface temperature gradient is debated as numerical climate models generally are not able to generate this proxy-inferred warm, temperate climate in the Arctic in conjunction with tropical temperatures not much warmer than modern values (e.g. Crowley and Zachos, 2000; Huber 
and Sloan, 2000; Huber and Caballero, 2003; Shellito et al., 2003). Additional evidence for the presence of a reduced equator-to-pole temperature gradient in the Eocene comes from the reconstructions of water isotopic signals (e.g. $\delta \mathrm{D}$ of $n$-alkanes, ${ }^{18} \mathrm{O}$ of cellulose; Feng and Epstein, 1995; Sessions et al., 1999; Fricke, 2003; Jahren et al., 2009; Pagani et al., 2006). As stable water isotopes (HDO and $\mathrm{H}_{2}^{18} \mathrm{O}$ ) in precipitation reflect (i) source-region, (ii) water volume loss during transport (rainout effects), (iii) local temperature, and (iv) the additive contribution of local water and mixing of different air masses (Craig and Gordon, 1965; Merlivat and Jouzel, 1979), the prevalence of a low meridional temperature gradient and associated changes in hydrological cycling should be reflected in the isotopic composition of Eocene precipitation.

The application of general circulation models (GCMs) adapted to include stable water isotope tracers allows for disentanglement of the various factors influencing the final isotopic composition of precipitation as recorded by proxy data (Joussaume et al., 1984; Jouzel et al., 1987; Noone and Simmonds, 2002; Schmidt et al., 2005; Lee et al., 2007) and provides an additional mechanism for evaluating modeled outcomes. Here we simulate the atmospheric response and subsequent hydrogen and oxygen isotope distributions in a world with a reduced meridional temperature gradient in an effort to enhance our understanding of the Early/Middle Eocene hydrological cycle. Model results are compared to hydrogen isotope estimates of precipitation for this interval to further evaluate proxy-based climate reconstructions that suggest the presence of a reduced meridional temperature gradient at this time.

\section{Methods}

\subsection{Model description}

To simulate the isotopic composition of precipitation and water vapor, as well as the climatological conditions during the Early/Middle Eocene, we use an adapted version (isoCAM3) of the National Center for Atmospheric Research (NCAR) Community Atmosphere Model version 3 (CAM3, Collins et al., 2006). IsoCAM3 incorporates a third generation isotope tracer scheme (Noone and Sturm, 2010), which is based on the earlier isotopic scheme of Noone and Simmonds (2002) but includes a more sophisticated treatment of surface exchange and cloud processes to make use of the multiple water phases (vapor, liquid and ice) predicted by CAM (e.g. Noone, 2003; Noone and Sturm, 2010). IsoCAM3 is coupled to a dynamic land surface model (CLM3: Bonan et al., 2002; Oleson et al., 2004) in which the isotopic composition of terrestrial water and evapotranspiration is accounted for by a simple two-bucket scheme based on the model of Noone and Simmonds (2002).

\subsection{Boundary conditions and experimental design}

Using isoCAM3, we simulate global patterns of stable water isotopes for the Eocene Azolla interval (EO-AZOLLA) and for a modern day control case (MOD). All simulations are atmosphere only with fixed sea surface temperatures (SSTs) and simulate the $\mathrm{H}_{2} \mathrm{O}$, HDO and $\mathrm{H}_{2}^{18} \mathrm{O}$ content in all existing water phases and transitions between those phases. The modern day simulation was set up with modern boundary conditions and forcings (e.g. atmospheric $p \mathrm{CO}_{2}$ ). The global mean oceanic $\delta \mathrm{D}$ and $\delta^{18} \mathrm{O}$ isotopic composition is kept constant and was set to VSMOW. For the Early/Middle Eocene simulation, we incorporated realistic, Eocene, topography, land surface conditions, and vegetation as boundary conditions (described in Sewall et al., 2000). Orbital parameters were set to modern day configuration. The EO-AZOLLA simulation was initialized using the atmospheric state from the equilibrium simulation of a fully coupled CCSM1.4 Eocene run (as described in Huber and Nof, 2006). Estimates for Early/Middle Eocene atmospheric $\mathrm{pCO}_{2}$ are uncertain, varying between $\sim 400$ and
3500 ppm (c.f. Zachos et al., 2008; Pearson and Palmer, 2000). Here we set greenhouse gas concentrations to $2000 \mathrm{ppm}\left(\mathrm{CO}_{2}\right)$ and $700 \mathrm{ppb}\left(\mathrm{CH}_{4}\right)$. Additional experiments (not shown) with higher (3000 ppm) and lower (800 ppm) $\mathrm{CO}_{2}$ concentrations showed very minor changes in precipitation $\delta \mathrm{D}$ compared to concentrations of 2000 ppm.

Tropical Eocene sea surface temperatures simulated by the fully coupled CCSM1.4 Eocene run of Huber and Nof (2006) were found to be consistent with SST estimates of $33^{\circ} \mathrm{C}$ (Pearson et al., 2007) from Tanzanian sediments from the Early/Middle Eocene. These mean annual SSTs at $19^{\circ} \mathrm{S}$ paleolatitude, were reconstructed based on $\mathrm{TEX}_{86}$ measurements using the Schouten et al. (2003) calibration for warm SSTs. Modeled high latitude temperatures from the fully coupled CCSM1.4 Eocene run were, however, colder than available TEX $_{86}$ SST estimates from the Early/Middle Eocene Arctic (Mean annual SST $=9.4{ }^{\circ} \mathrm{C}$; Brinkhuis et al., 2006, using the Schouten et al., 2002 calibration) (Fig. 1; grey dotted line). For our EO-AZOLLA simulation, we, therefore, modified SSTs from the fully coupled CCSM1.4 Eocene run, using a fixed, zonally constant, offset based on the Brinkhuis et al. (2006) TEX $_{86}$ SST estimates from the Early/Middle Eocene Arctic. Global meridional SSTs were scaled accordingly between the Tropics and the Arctic (Fig. 1; red line), while preserving the spatial variability of the CCSM1.4 run. This way, we combine the modeled SST patterns with the more realistic proxy-values. The applied seasonal SST cycle smoothed the imposed offset in the model and was derived from two reconstructions based on intra-shell stable oxygen isotope profiles of shallow-water gastropods. Near Southern England, a seasonality of $10-12{ }^{\circ} \mathrm{C}$ has been suggested (Andreasson and Schmitz, 2000), while the Early/Middle Eocene US Gulf coast experienced an $8-9{ }^{\circ} \mathrm{C}$ temperature change over the year (Andreasson and Schmitz, 2000). For the Arctic, the imposed seasonal SSTs varied between $2{ }^{\circ} \mathrm{C}$ in February and $19.5^{\circ} \mathrm{C}$ in September. Implied ocean heat transport produced with the simulation using this SST gradient is similar to ocean heat transport in the fully coupled simulation. Global mean $\delta \mathrm{D}$ and $\delta^{18} \mathrm{O}$ of seawater were adjusted to reflect globally ice-free conditions ( $-8 \%$ for $\delta \mathrm{D}$ and $-1 \%$ ofor $\delta^{18} \mathrm{O}$, respectively). According to Schmidt et al. (1999), there is only a $\sim 1.5 \%$ d difference in $\delta^{18} \mathrm{O}$ between low and high latitudes in the open ocean. These differences are caused by the net transport of isotopically depleted water vapor away from the tropics towards the poles, with more enriched areas where evaporation exceeds precipitation. Regional differences of ${ }^{18} \mathrm{O}$ and $\delta \mathrm{D}$ in seawater are small compared to differences in precipitation and are therefore not modeled here. The model simulations were integrated for $30 \mathrm{yr}$ at a spectral resolution of T31 $\left(\sim 3.75^{\circ}\right.$ lat. $\times 3.75^{\circ}$ lon) and results may be somewhat sensitive to resolution. The last $10 \mathrm{yr}$ were averaged and used for subsequent evaluation.

\subsection{Early/Middle Eocene n-alkane $\delta D$ measurements}

Three sediment samples from different locations from the same time interval were used to obtain measurements of $\delta \mathrm{D}$ of terrestrial $\mathrm{C}_{29}$ n-alkanes. From South to North: (1) Carcoselle Quary, Possagno, Italy (as described in Agnini et al., 2006), sample 34340 (2) Danish Outcrops, Lillebælt Clay Formation, Bed L2, sample 8B (as described in Heilmann-Clausen et al., 1985) and (3) IODP Leg 151, Hole 913b, Norwegian Greenland Sea, $75^{\circ} 29.356^{\prime}$ N $6^{\circ} 56.810^{\prime}$ W (water depth: $3318.4 \mathrm{~m}$ ), samples core $48 \mathrm{x}$ interval $1 \mathrm{w}$ section $20-22 \mathrm{~cm}$, and core $47 \mathrm{x}$ interval $2 \mathrm{w}$, section $70-72 \mathrm{~cm}$.

Between 0.5 and $5 \mathrm{~g}$ of freeze-dried sediment was powdered and subsequently extracted with an Accelerated Solvent Extractor (Dionex) using a dichloromethane (DCM)-methanol (MeOH) mixture $(9: 1, v / v)$. The obtained lipid fractions were separated by column chromatography using an elution sequence of hexane/DCM $(9: 1 \mathrm{v} / \mathrm{v})$ and $\mathrm{DCM} / \mathrm{MeOH}(1: 1 \mathrm{v} / \mathrm{v})$. All extracts were de-sulpherized using activated copper. To purify the apolair fraction, cyclic and branched alkanes in the hydrocarbon fraction were separated from normal 


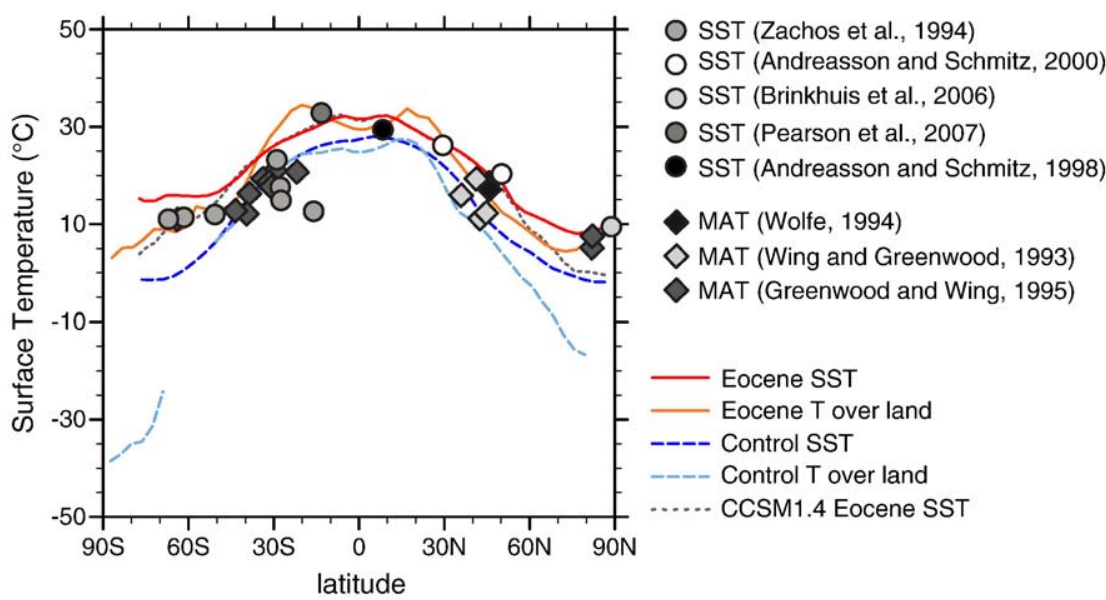

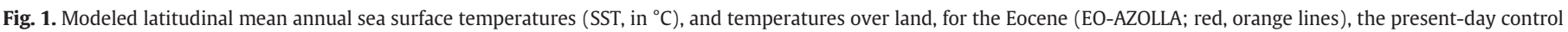

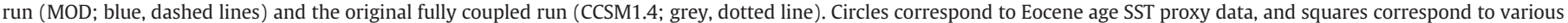
proxy-based estimates of mean annual air temperature (MAT).

alkanes by adduction with urea, using a mixture of methanolsaturated urea, pentane and acetone $\left(200 \mu \mathrm{l}\right.$ each). Frozen and $\mathrm{N}_{2^{-}}$ dried urea crystals were washed with hexane to extract cyclic/ branched alkanes. Remaining urea crystals were dissolved in $500 \mu \mathrm{l}$ of double distilled $\mathrm{H}_{2} \mathrm{O}$ (MiliQ) and $500 \mu \mathrm{l}$ of methanol, and extracted with hexane to yield the purified $n$-alkane fraction.

Compounds were identified by GC/MS (Thermo Trace GC Ultra). Samples were on-column injected at $70^{\circ} \mathrm{C}$, on a CP-Sil 5CB fused silica column $(30 \mathrm{~m} \times 0.32 \mathrm{~mm}$ i.d., film thickness $0.1 \mu \mathrm{m})$ with helium as the carrier gas set at constant pressure $(100 \mathrm{KPa})$. The oven was programmed to $130{ }^{\circ} \mathrm{C}$ at $20^{\circ} \mathrm{C} / \mathrm{min}$ and then to $320^{\circ} \mathrm{C}$ at $4{ }^{\circ} \mathrm{C} / \mathrm{min}$, followed by an isothermal hold for $20 \mathrm{~min}$.

The adducted $n$-alkane fractions were analysed for stable hydrogen isotopic compositions using isotope ratio monitoring gas chromatography-mass spectrometry (GC-IRMS). For the samples from the Danish Outcrops and IODP Leg 151 a Thermo Finnigan MAT 253 mass spectrometer was used with a J\&W Scientific DB-1 capillary column $(60 \mathrm{~m} £ 0.25 \mathrm{~mm} £ 0.25 \mathrm{~mm})$ at Yale University. The sample from Possagno was measured using a ThermoFinnigan DeltaPlus XP mass spectrometer at Utrecht University. A similar column and oven program was used as described above, though with a constant flow of $1 \mathrm{ml} / \mathrm{min}$. Conversion of organic hydrogen to $\mathrm{H}_{2}$ was conducted at $1400{ }^{\circ} \mathrm{C}$. The $\mathrm{H} 3$ factor was determined daily on the isotope mass spectrometer, and was always below 5 . Schimmelman Mixture A, B, and C (Schimmelmann, Biogeochemical Laboratories, Indiana University), were run twice-daily alternately to correct reference gas values. Co-injected squalane with a known $\delta \mathrm{D}$ isotopic composition (also Schimmelman) was used as internal standard to monitor performance. Hydrogen isotopic compositions are reported relative to VSMOW and are based on duplicate analyses, where possible, of well-resolved peaks ( $>500 \mathrm{mV}$ ) and represent averaged values. The precision of isotopic measurements of $\mathrm{H}_{2}$ reference gas after $\mathrm{H} 3$ correction was 0.2 or better. The average standard deviation per day for the separate $n$-alkanes was below $4 \%$.

\section{Results}

\subsection{Climate output Eocene}

The Early/Middle Eocene simulation (EO-AZOLLA) is largely controlled by the imposed SST gradient. Overall, EO-AZOLLA, using $\mathrm{TEX}_{86}$-derived Arctic mean annual SSTs of $9.4^{\circ} \mathrm{C}$, is warmer and wetter than the present-day control run (MOD) (Figs. 1 and 2). Results of the Eocene simulation show an average global surface temperature of $23.9{ }^{\circ} \mathrm{C}$. However, simulated continental interior cold month mean (CMM) temperatures in EO-AZOLLA (not shown) dip well below freezing (down to $-10{ }^{\circ} \mathrm{C}$ at certain locations) in the continental interiors of North America and Asia. Closer to the Arctic, continental CMM temperatures of $0-4{ }^{\circ} \mathrm{C}\left(\right.$ at $79{ }^{\circ} \mathrm{N}$ ) are simulated by the model. In our EO-AZOLLA simulation, evaporation (E) and precipitation $(\mathrm{P})$ rates are enhanced compared to MOD and the atmospheric water vapor loading is higher due to lower lapse rates and higher atmospheric temperatures, with the total amount of precipitable water higher at all latitudes (not shown) by on average $13.8 \mathrm{~mm}$. In mid-latitude regions, E-P values are about the same for MOD and EO-AZOLLA, but between $50-85^{\circ} \mathrm{N}$ and 70-90 ${ }^{\circ} \mathrm{S}$, excess precipitation is higher in the EO-AZOLLA simulation than in MOD, amounting to up to $1.6 \mathrm{~mm} /$ day.

Overall, annual mean meridional circulation in EO-AZOLLA is similar to present-day, with two tropical Hadley cells, the Ferrel cells at midlatitude and the Polar cells at high latitudes. The annual mean $850 \mathrm{mb}$ transient eddy kinetic energy is generally lower in the Eocene than in the modern simulation, at mid-latitudes around $20 \mathrm{~m}^{2} / \mathrm{s}^{2}$ lower than the Present-day control, reflecting weaker storm tracks (globally averaged $\sim 7 \mathrm{~m}^{2} / \mathrm{s}^{2}$ less; not shown). Annual averaged meridional heat fluxes are also reduced in EO-AZOLLA, especially at mid-latitudes (Fig. 3a). Transient eddy moisture transport, on the other hand, is quite similar at low latitudes, while significantly higher (by $0.6 \mathrm{~m} / \mathrm{s} \mathrm{g} / \mathrm{kg}$ ) at higher latitudes $\left(>50^{\circ} \mathrm{N}\right.$ and $\left.>65^{\circ} \mathrm{S}\right)$ in EO-AZOLLA (Fig. 3b).

\subsection{Modeled isotopic composition of precipitation}

\subsubsection{Present-day control run}

The modeled isotopic composition of precipitation for the presentday is shown in Fig. 4a and b (black). In Fig. 5a, the annual global distribution of precipitation weighted $\delta \mathrm{D}$ in the MOD simulation is shown.

\subsubsection{Early/Middle Eocene run}

The effect of an Early/Middle Eocene reduced equator-to-pole temperature gradient (as shown in Fig. 1) on the isotopic composition of precipitation is shown in Fig. 4a and b, and the modeled annual global distribution of precipitation weighted $\delta \mathrm{D}$ in the EO-AZOLLA simulation is shown in Fig. $5 c$. The range of absolute $\delta D$ and $\delta^{18} \mathrm{O}$ values is substantially reduced for the Eocene compared to MOD (Figs. 4 and 5; zonal mean precipitation $\delta \mathrm{D}$ red versus blue line). 


\subsection{Measured Early/Middle Eocene n-alkane $\delta D$}

Compound specific $\delta \mathrm{D}$ of $n$-alkanes with a strong odd over even predominance from three sediment samples, specifically from the Azolla interval, were measured. The samples came from outcrops in Possagno, Italy, the Lillebælt Clay Formation, Denmark, and an IODP sediment core taken off the coast of Greenland (IODP Leg 913B). That the samples from Denmark and Greenland are truly synchronous with the Azolla interval is evident from the presence of $1, \omega 20 \mathrm{C}_{32}-\mathrm{C}_{36}$ diols in the sediment extracts (unpublished results), which are biomarkers for Azolla (Speelman et al., 2009b). Measured $C_{29} n$-alkane $\delta \mathrm{D}$ varied between -130 (Possagno) to $-204 \%$ (Greenland). Data from contemporary environments generally suggests apparent hydrogen isotope fractionation between source water and long-chain $n$-alkanes $\left(C_{29}\right.$ and $\left.C_{27}\right)$ of $96 \%$ to $130 \%$ (Sachse et al., 2004, 2006; Yang et al., 2009). These values differ between plant species and with differing environmental conditions (Liu et al., 2006; Sachse et al., 2006). Using the range of observed fractionation values, Early/Middle Eocene precipitation $\delta \mathrm{D}$ can be computed from the measured $C_{29} n$-alkane $\delta \mathrm{D}$ values (Table 1). The three samples from Western Europe show a clear latitudinal trend, with increasing depletion from South to North.

\section{Discussion}

\subsection{Climate validation: Eocene versus proxy data and Present-day climate simulation}

The EO-AZOLLA simulation is in broad agreement with proxy reconstructed environmental conditions in terms of annual mean temperature (Fig. 1) (but not cold month mean), humidity (not shown) and precipitation (Fig. 2). The imposed Early/Middle Eocene forcing thus reproduces a climate that agrees well with proxy data in locations around the globe. The Eocene simulation (EO-AZOLLA) is on average $8.5^{\circ} \mathrm{C}$ warmer than the modern day control (MOD). Modeled latitudinal surface temperatures are shown and compared to various Eocene proxy-derived temperature estimates in Fig. 1. Recrystallization

Table 1

Comparison of modeled and reconstructed mean annual precipitation rates ( $\mathrm{mm} / \mathrm{yr}$ ) for the Eocene Azolla interval ( 49 Ma).

\begin{tabular}{|c|c|c|c|c|}
\hline Location & Age (Ma) & $\begin{array}{l}\text { Reconstructed } \\
\text { precipitation }^{\mathrm{a}} \\
(\mathrm{mm} / \mathrm{yr})\end{array}$ & $\begin{array}{l}\text { Modeled } \\
\text { precipitation }^{\mathrm{b}} \\
(\mathrm{mm} / \mathrm{yr})\end{array}$ & Reference \\
\hline $\begin{array}{l}\text { US Western } \\
\text { Interior }\end{array}$ & $49-51$ & $1040-1360$ & $950-1540$ & Wilf et al., 1998 \\
\hline $\begin{array}{l}\text { US Western } \\
\text { Interior }\end{array}$ & $49-51$ & $1160-2770$ & $950-1540$ & $\begin{array}{l}\text { Wing and } \\
\text { Greenwood, } \\
1993\end{array}$ \\
\hline $\begin{array}{l}\text { Republic, } \\
\text { WA, US }\end{array}$ & $49-50$ & 1150 & $1150(1140-1190)$ & $\begin{array}{l}\text { Greenwood } \\
\text { et al., } 2005\end{array}$ \\
\hline $\begin{array}{l}\text { Changchang, } \\
\text { China }\end{array}$ & $\begin{array}{l}\text { Early } \\
\text { Middle } \\
\text { Eocene }\end{array}$ & 949 & 988 (890-1710) & Yao et al., 2009 \\
\hline $\begin{array}{l}\text { Mahenge, } \\
\text { Tanzania }\end{array}$ & $\max .46$ & $640-780$ & $840(460-840)$ & $\begin{array}{l}\text { Jacobs and } \\
\text { Herendeen, } \\
2004\end{array}$ \\
\hline $\begin{array}{l}\text { Yakutat, } \\
\text { Alaska, US }\end{array}$ & $\begin{array}{l}\text { Early } \\
\text { Middle } \\
\text { Eocene }\end{array}$ & $>1500$ & $2280(1655-2500)$ & Wolfe, 1994 \\
\hline $\begin{array}{l}\text { NW Pacific, } \\
\text { US }\end{array}$ & $\begin{array}{l}\text { Early } \\
\text { Middle } \\
\text { Eocene }\end{array}$ & $>1500$ & $1770(1490-2000)$ & Wolfe, 1994 \\
\hline $\begin{array}{l}\text { Axel } \\
\text { Heiberg }\end{array}$ & 49 & 1200 & $500(450-650)$ & $\begin{array}{l}\text { Eldrett et al., } \\
2009\end{array}$ \\
\hline
\end{tabular}

a Precipitation rate estimates from certain regions or locations as indicated.

b Modeled precipitation rate estimates of corresponding paleo-locations in the model. Values between brackets are taken from multiple surrounding grid-cells in order to characterize the uncertainty in the modelled value arising from uncertainty in the paleo-location of the proxy sites and the coarse resolution of the model.

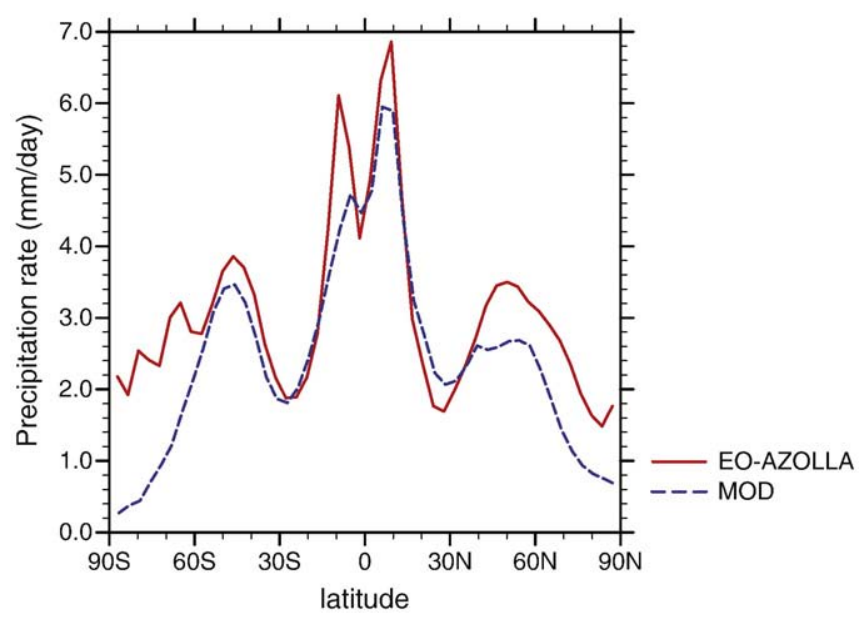

Fig. 2. Zonal averages of mean annual precipitation rates ( $\mathrm{mm} /$ day), for both the Eocene (red, solid line) and present-day control run (blue, dashed line).

of forams (as described in Pearson et al., 2007), possibly leads to underestimation of sea surface temperatures, explaining the (small) temperature offset between the modeled values and the values as inferred by Zachos et al. (1994). As observed before (e.g. Barron et al., 1995; Sloan et al., 2001), imposed warm high latitude SSTs have little impact on extratropical continental interior temperatures. Simulated continental interior cold month temperatures in EO-AZOLLA (not shown) are colder than indicated by proxy data (Basinger, 1991; Markwick, 1994; Sloan, 1994; Wolfe, 1994; Greenwood and Wing, 1995). Closer to the Arctic, cold month mean estimates of $0-8.6^{\circ} \mathrm{C}$ ( cf. $0-4{ }^{\circ} \mathrm{C}$ Basinger et al., $1994 ; 3.3-8.6{ }^{\circ} \mathrm{C}$ Wolfe, $1994 ;-0.8-3.6{ }^{\circ} \mathrm{C}$, Greenwood and Wing, 1995$)$ do agree well with values $\left(0-4{ }^{\circ} \mathrm{C}\right.$ at $\left.79^{\circ} \mathrm{N}\right)$ produced by the model.

The occurrence of a fresh surface water layer in the Arctic Ocean during the Azolla interval (Brinkhuis et al., 2006) could be explained by an intensified hydrological cycle with precipitation exceeding evaporation at high latitudes as suggested earlier by Manabe (1997) and Huber et al. (2003), in conjunction with the very restricted connection with the open ocean dictated by the paleogeography (Brinkhuis et al., 2006). Indeed, model predicted zonal mean annual precipitation rates are notably higher in the Eocene, especially in the Arctic and Antarctic regions (Fig. 2). Available estimates of Early/ Middle Eocene ( $49 \mathrm{Ma})$ precipitation rates based on leaf-area and bioclimatic analysis of fossil floras support the modeled values (Table 1), except at Axel Heiberg Island where the model underestimates precipitation.

The strength of mid-latitude (eddy driven) circulation depends on mean global temperature as well as on meridional temperature differences (Caballero and Langen, 2005), and, in agreement with this, the Eocene simulation exhibits reductions in the strength of midlatitude circulation. Weaker Eocene storm tracks are also reflected in lower transient eddy heat transport. However, at a higher global mean temperature it is possible to transport more latent heat, even with a reduced meridional temperature gradient. This is reflected in transient eddy moisture transport which is in EO-AZOLLA only slightly lower at mid-latitudes and significantly higher $(\sim 0.6 \mathrm{~m} / \mathrm{s} \mathrm{g} /$ $\mathrm{kg}$ ) at higher latitudes ( $>50^{\circ} \mathrm{N}$ and $>65{ }^{\circ} \mathrm{S}$ ) than in MOD (Fig. 3b). In agreement with the interpretation of Pagani et al. (2006), the simulated increase in poleward moisture transport, in EO-AZOLLA, results in an enhanced high latitude precipitation as well as in a net precipitation reduction in sub-tropical areas and part of the midlatitudes (Fig. 2). These changes in regional water balance are expected to significantly influence the regional and global isotopic composition of meteoric water. 
a

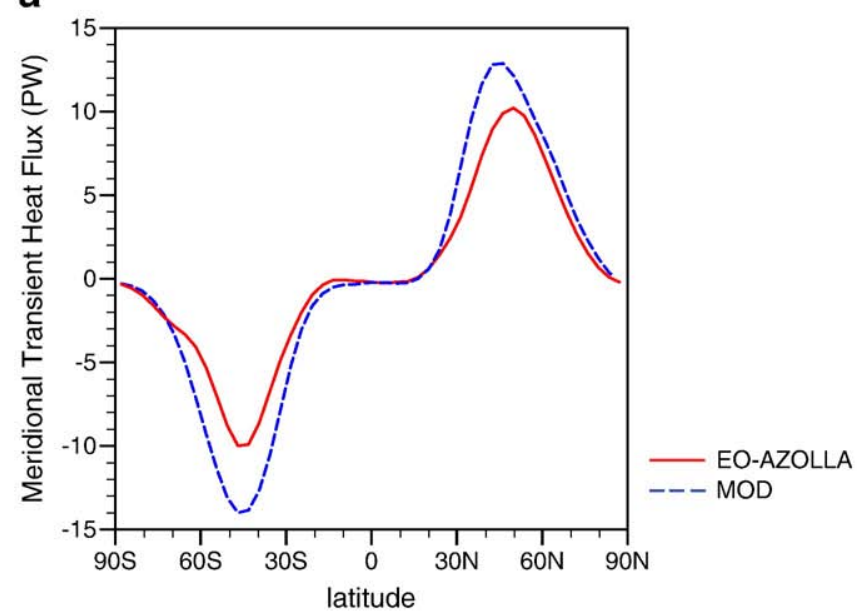

b

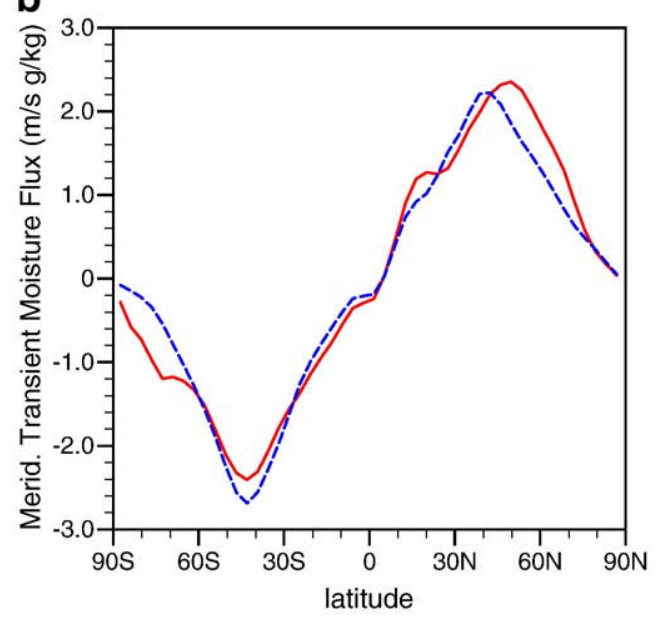

Fig. 3. (a) Modeled zonal mean annual meridional heat transport (PW), for MOD (dashed blue) and EO-AZOLLA (red), and (b) zonal mean annual meridional moisture transport $(\mathrm{g} / \mathrm{kg})$.

\subsection{Present-day isotope simulation versus GNIP data}

Comparison of previous isoCAM3 present-day simulations to observed isotopic patterns in the Global Network of Isotopes in Precipitation (GNIP) database assembled by the International Atomic Energy Agency (IAEA/WMO, 2006) shows good agreement on global and regional scales (Noone, 2003). Our MOD simulation at T31 also captures the main features of the GNIP global distribution of $\delta^{18} \mathrm{O}$ and $\delta \mathrm{D}$ (Fig. 5b) with modeled precipitation $\delta^{18} \mathrm{O}$ and $\delta \mathrm{D}$ still following the expected linear trend known as the meteoric water line: $\delta \mathrm{D}=8^{*} \delta^{18} \mathrm{O}+$ 10 (Craig, 1961) (Fig. 4a). In line with the GNIP data, our MOD run describes an arcuate trend on the diagram with virtually no dependence of $\delta \mathrm{D}$ on temperature above $15^{\circ} \mathrm{C}$ and a gradually increasing $\delta \mathrm{D} / \mathrm{T}$ slope with decreasing temperature (cf., Masson-Delmotte et al., 2008) (black crosses, Fig. 4b). The model also succeeds in capturing the correlation between mean annual $\delta \mathrm{D}$ and precipitation (amount effect) over warm tropical regions (black crosses, Fig. 4b). The latitude and continental effects (e.g. Ingraham, 1998) are clearly reproduced in the time mean statistics.

\subsection{Model-data comparison for EO-AZOLLA isotope values}

The assumption of a constant relation between $\delta \mathrm{D}$ and $\delta^{18} \mathrm{O}$ remains valid for the Eocene simulation (as predicted from equilibrium theory; Craig, 1961), with precipitation $\delta \mathrm{D}$ and $\delta^{18} \mathrm{O}$ from EO- a

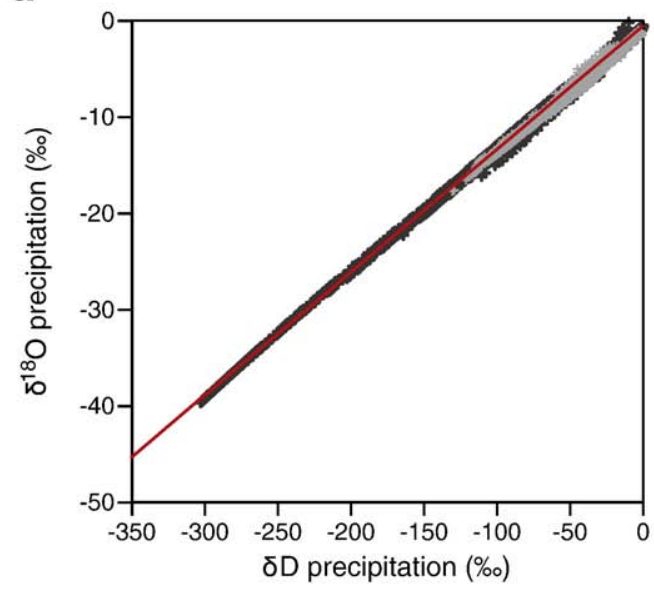

b

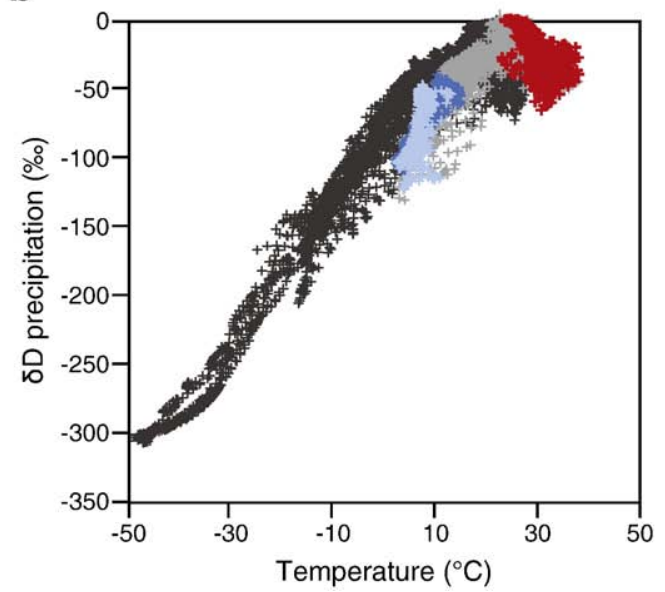

Fig. 4. (a) Modeled mean annual isotopic composition of precipitation (\% VSMOW) of $\delta \mathrm{D}$ versus $\delta^{18} \mathrm{O}$, for the present-day control run (black) and for the Eocene (light grey). The dots represent the $\delta \mathrm{D}$ and $\delta^{18} \mathrm{O}$ of precipitation for each model grid point. The red line represents the Global Meteoric Waterline $\left(\delta D=8 * \delta^{18} \mathrm{O}+10 \%\right.$ ) (Craig, 1961). (b) The relationship between annual mean $\delta \mathrm{D}$ in precipitation and annual mean temperature at the surface $\left({ }^{\circ} \mathrm{C}\right)$ for model output of present-day (black) and Eocene simulations. For EO-AZOLLA regions are colored: red for the tropics $\left(20^{\circ} \mathrm{S}-20^{\circ} \mathrm{N}\right)$, grey for the mid-latitudes $\left(20^{\circ}-70^{\circ}\right)$, light blue for the Arctic $\left(70-90^{\circ} \mathrm{S}\right)$ and blue for the Antarctic $\left(70-90^{\circ} \mathrm{S}\right)$.

AZOLLA plotting on the meteoric waterline (Fig. 4a). In Fig. 4, precipitation $\delta \mathrm{D}$ vs. $\delta^{18} \mathrm{O}$ values for the entire world (every grid-cell with a 10-yr average) are plotted. On a global scale, average deuterium-excess values (d-excess) in precipitation as defined by Dansgaard (1964) from the meteoric water line (Craig, 1961) (dexcess $=\delta D-8^{*} \delta 180$ ) end up close to 10 , for both the Present-day and the Eocene.

For specific regions distinct differences, as a consequence of variation in kinetic fractionation, are observed. On average, $d$-excess is $6.5 \%$ for the Eocene Arctic. For this region, modern model and data dexcess values are higher and vary between 4 and 14\% (Frankenberg et al., 2009; GNIP). Sea surface conditions that define evaporation such as relative humidity, temperature and, to a lesser degree, wind speed are key parameters for the deuterium-excess of atmospheric water vapor and precipitation (Merlivat and Jouzel, 1979). The modeled low d-excess values are consistent with higher Eocene Arctic temperatures and high relative humidity levels at a specific SST. The lowest amount weighted annual precipitation d-excess values are found over the continents, in summer June/July ( $2 \%$ o), coinciding with lower levels of relative humidity (60\%). This indicates that, in summer, $\delta \mathrm{D}$ of precipitation is influenced by the evaporative 
enrichment of falling raindrops (subcloud evaporation), as described by Dansgaard (1964). Precipitation $\delta D$ values decrease there from January to July, with d-excess values exhibiting strong linear correlation with precipitation $\delta \mathrm{D}$ (d-excess $=-0.13 * \delta \mathrm{D}-5.1\left(\mathrm{r}^{2}\right.$ 0.97)). Between August and December d-excess values are higher for the same precipitation $\delta \mathrm{D}$, coinciding with relatively higher relative humidity levels.

For verification, EO-AZOLLA results in terms of isotopic composition of precipitation can be tested against reconstructions of the $\delta \mathrm{D}$ of environmental water for the Early/Middle Eocene Azolla interval; Fig. 5c and Table 2 show the results for EO-AZOLLA precipitation weighted isotopic composition compared with proxy data estimates available for this time interval ( 49 Ma). Besides the $n$-alkane inferred precipitation $\delta \mathrm{D}$ presented here, the Eocene precipitation estimates (Fig. 5c; Table 2) have been derived via a suite of different approaches and proxies, including determination of hydrogen isotopic composition of kaolinite (Mulch et al., 2006), measurement of $\delta D$ of $n$-alkanes from lignite layers (Jahren et al., 2009), and determination of $\delta^{18} \mathrm{O}$ of fossil cellulose (Jahren and Sternberg, 2003). The model not only accurately captures general trends, but also absolute values are in reasonable agreement and fall well within the confidence intervals associated with the available proxy data for this specific time interval. The only region where model simulated isotopic composition of precipitation deviates from available reconstructed values is at Axel Heiberg Island, which is likely attributable to the imposed and fixed isotopic composition of the Arctic Ocean ( $\delta \mathrm{D}=-8 \%$. VSMOW) in the EO-AZOLLA simulation. This imposed condition does not take into account freshening of the Arctic Ocean water (Brinkhuis et al., 2006), which would render the surface water gradually more $\delta \mathrm{D}$ depleted. Hence the $\delta \mathrm{D}$ of water evaporated from the Arctic sea surface in EOAZOLLA is overestimated and precipitation falling in proximity of the Arctic has a $\delta \mathrm{D}$ at the high end of the proxy-defined parameter space
( $-168 \%$ o to $-131 \%$, Jahren et al., 2009). Overall, we find a good correlation between our model results, using a reduced meridional temperature gradient, and the available proxy data for the Early/ Middle Eocene Azolla interval.

\subsection{Effect of a reduced equator-pole temperature gradient on the isotopic composition of precipitation}

A reduced temperature gradient dictates less isotopic distillation (Rayleigh condensation) during poleward transport. It follows from Precipitation (Fig. 2) and Evaporation-Precipitation (not shown) that excess precipitation at the high latitudes is higher (i.e. relatively less evaporation) in the EO-AZOLLA simulation than in MOD. As more water vapor is transported to (extreme) high latitudes along a reduced meridional temperature gradient, less rainout occurs along the airmass's trajectory (due to less cooling), which then leads to less isotopic depletion in precipitation at Eocene high latitudes relative to the modern simulation.

The major spatial relationships observed for the modern (from GNIP data (IAEA/WMO, 2006)) are retained in EO-AZOLLA (Fig. 5), with $\delta \mathrm{D}$ at low latitudes depending primarily on the balance between precipitation and evaporation and decreasing with decreasing temperature, poleward, with increased distance from the coast, and with increased elevation (this is especially clear in the (albeit lower) Eocene Rocky Mountains) (Fig. 5c). Similar to the modern situation, in the tropical regions (20 ${ }^{\circ} \mathrm{N}-20^{\circ} \mathrm{S}$ ) a recycling of water through evaporation of falling rain is observed in the convective precipitation, resulting in relatively depleted isotopic values (Worden et al., 2007; Risi et al., 2008) (Fig. 4b; red crosses). In EO-AZOLLA, the region characterized by tropical (i.e. warmer) sea surface temperatures reaches into the mid-latitudes (Fig. 1). This effectively expands the region over which the moist tropical atmosphere can be considered
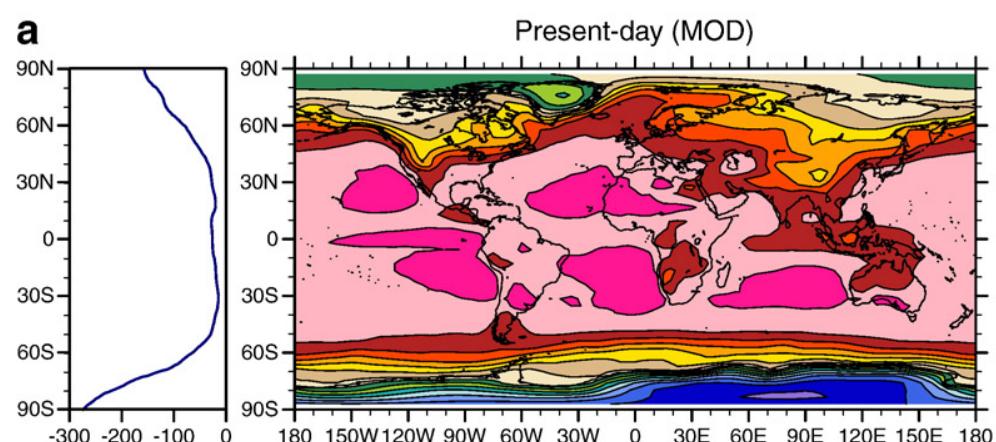

zonal $\delta \mathrm{D}$ precipitation (\%o)
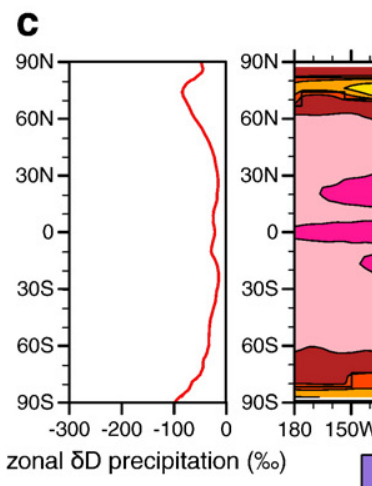

Eocene (EO-AZOLLA)

zonal $\delta \mathrm{D}$ precipitation $(\%)$

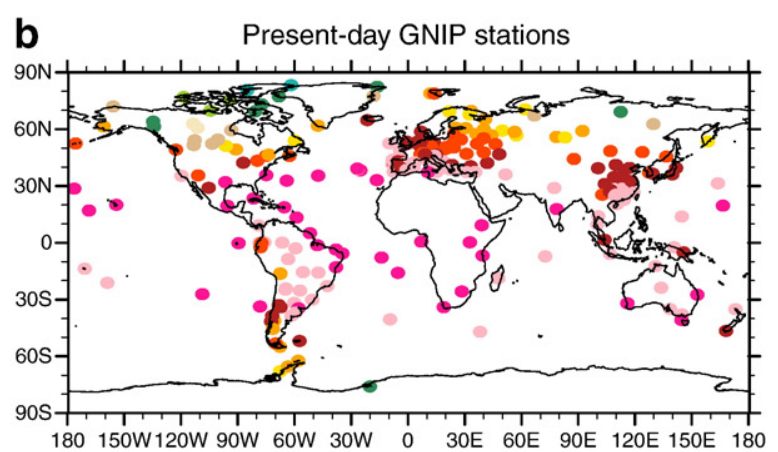

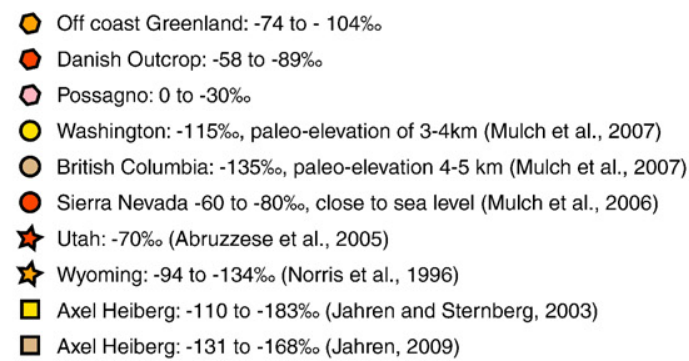

$-300-260-220-180-140-100-80-60-40-200$ precipitation weighted $\delta \mathrm{D}(\%)$

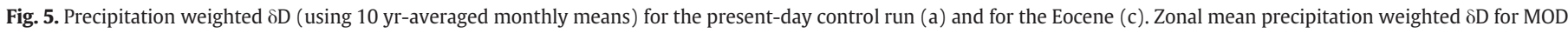

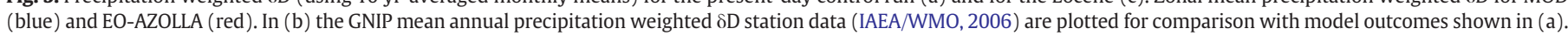
(c) Model-data comparison for Eocene precipitation weighted $\delta \mathrm{D}$, where the colors of the symbols correspond to the color scale of the underlying plot. 
Table 2

Comparison of modeled weighted (using 10 yr-averaged monthly means) precipitation $\delta \mathrm{D}$ values (\%) with $\mathrm{C}_{29} n$-alkane inferred precipitation $\delta \mathrm{D}$ and available precipitation isotopic composition estimates (\%) for the Eocene Azolla interval ( $49 \mathrm{Ma})$.

\begin{tabular}{|c|c|c|c|c|}
\hline Location & $\begin{array}{l}\text { Age } \\
\text { (Ma) }\end{array}$ & $\begin{array}{l}\text { Reconstructed } \delta D \\
\text { precipitation }^{\mathrm{a}}(\% \circ)\end{array}$ & $\begin{array}{l}\text { Modeled } \delta \mathrm{D} \\
\text { precipitation }^{\mathrm{b}}(\%)\end{array}$ & Reference \\
\hline $\begin{array}{l}\text { Possagno, } \\
\text { Italy }\end{array}$ & $\begin{array}{l}\text { Early/ } \\
\text { Middle } \\
\text { Eocene }\end{array}$ & -0 to -34 & $-24(-20$ to -26$)$ & this study \\
\hline $\begin{array}{l}\text { Lillebaelt, } \\
\text { Denmark }\end{array}$ & $\sim 49$ & -59 to -93 & $-58(-45$ to -66$)$ & this study \\
\hline $\begin{array}{l}\text { IODP } \\
\text { 151Greenland }\end{array}$ & $\sim 49$ & -74 to -107 & $-89(-73$ to -101$)$ & this study \\
\hline Kettle, WA,US & 49.1 & -110 to -120 & -117 ( -107 to -122$)$ & $\begin{array}{l}\text { Mulch } \\
\text { et al., } \\
2007\end{array}$ \\
\hline Shuswap, BC, US & $\begin{array}{l}49- \\
47.1\end{array}$ & -130 to -140 & $-107(-107$ to -116$)$ & $\begin{array}{l}\text { Mulch } \\
\text { et al., } \\
2007\end{array}$ \\
\hline $\begin{array}{l}\text { Sierra Nevada, } \\
\text { CA, US }\end{array}$ & $50-40$ & -60 to -80 & $-78(-51$ to -100$)$ & $\begin{array}{l}\text { Mulch } \\
\text { et al., } \\
2006\end{array}$ \\
\hline Axel Heiberg & 49 & -110 to -183 & $-79(-60$ to -97$)$ & $\begin{array}{l}\text { Jahren } \\
\text { and } \\
\text { Sternberg, } \\
2003\end{array}$ \\
\hline Axel Heiberg & 49 & -131 to -168 & $-79(-60$ to -97$)$ & $\begin{array}{l}\text { Jahren } \\
\text { et al., } \\
2009\end{array}$ \\
\hline Salina, UT, US & $\begin{array}{l}51- \\
46.5\end{array}$ & -70 & $-76(-76$ to -109$)$ & $\begin{array}{l}\text { Abruzzese } \\
\text { et al., } \\
2005\end{array}$ \\
\hline $\begin{array}{l}\text { Lake Gosiute, } \\
\text { WY, US }\end{array}$ & $\begin{array}{l}\text { Early/ } \\
\text { Middle } \\
\text { Eocene }\end{array}$ & -94 to -134 & $-80(-76$ to -94$)$ & $\begin{array}{l}\text { Norris } \\
\text { et al., } \\
1996\end{array}$ \\
\hline
\end{tabular}

${ }^{a}$ Local Eocene precipitation $\delta \mathrm{D} /$ environmental water $\delta \mathrm{D}$ estimates, as well as ${ }^{18} \mathrm{O}$ values converted to $\delta \mathrm{D}$ with the meteoric waterline (Craig, 1961), as cited in referenced articles.

b Modeled mean annual averaged weighted precipitation $\delta \mathrm{D}$ values of corresponding paleo-locations in the model. Values between brackets are taken from multiple surrounding grid-cells in order to characterize the uncertainty in the modeled value arising from uncertainty in the paleo-location of the proxy sites and the coarse resolution of the model.

dominated by, and in quasi-equilibrium with, convective storm activity. The tropical rainfall recycling effect extends, therefore, into the mid-latitudes in EO-AZOLLA.

At mid- to high latitudes, EO-AZOLLA $\delta$ D values are found to be more depleted than MOD $\delta D$ at a certain temperature (Fig. 4b; grey, blue and light blue crosses). Moreover, as the model does not account for changes in surface water $\delta \mathrm{D}$ ( or $\delta^{18} \mathrm{O}$ ), the model possibly overestimates precipitation $\delta \mathrm{D}$ values in certain (high latitude) regions, where precipitation exceeds evaporation. The modeled offset in $\delta D$ between EO-AZOLLA and MOD at a certain temperature is not due entirely to the absence of continental ice sheets (which imposes an offset of only 8\%), but is consistent with changes in mixing characteristics during the passage of vapor from warmer low latitudes to cooler high latitudes in the presence of the reduced meridional temperature gradient (Noone, 2008). As the region over which convective precipitation prevails is expanded in EO-AZOLLA relative to MOD, and the contribution of convective precipitation to total precipitation is increased (EO-AZOLLA 77\% versus MOD 67\%), more rain comes down in convective storms, also at higher latitudes. Since convective precipitation generally consists of larger droplets it exchanges less with near-surface moisture while falling, leading to relatively more depleted precipitation $\delta \mathrm{D}$ values.

The most depleted values (between -40 and $-145 \%$ ) are observed at both poles (Fig. 4b; light blue and blue crosses, Fig. 5c). Looking at respective cells belonging to a certain region, mean annual regional $\delta \mathrm{D}_{\text {precip }} / \mathrm{T}$ slopes at high latitudes are found to be steeper in the Eocene (Arctic: $7.3 \% /{ }^{\circ} \mathrm{C}$ and Antarctic: $5.1 \% /{ }^{\circ} \mathrm{C}$ ) than in the present-day simulation (Arctic: $3 \% /{ }^{\circ} \mathrm{C}$ and Antarctic: $3.6 \% /{ }^{\circ} \mathrm{C}$, respectively). As the reduced temperature gradient allows the moisture transport to occur with reduced interaction with the surface, it can produce a slope for Eocene high latitudes closer to that predicted from Rayleigh theory than for present-day. The differences between Eocene regional $\delta D_{\text {precip }} / T$ slopes in the Arctic region $\left(7.3 \% /{ }^{\circ} \mathrm{C}, \mathrm{r}^{2}=0.3\right.$; Fig. $4 \mathrm{~b}$; light blue crosses) and around Antarctica $\left(5.1 \% \circ /{ }^{\circ} \mathrm{C}, \mathrm{r}^{2}=0.9\right.$; Fig. $4 \mathrm{~b}$; blue crosses), further result from the imposed reduced meridional temperature gradient over the northern hemisphere, differences in the simulated cloud conditions - tied to processes that influence isotopic fractionation such as temperature dependence, ice/liquid partitioning and supersaturation, and the type of clouds that prevail - and the more complex geography in the Arctic. The latter is also reflected in the more scattered relation between $\delta \mathrm{D}_{\text {precip }}$ and $\mathrm{T}$ in the Arctic (Fig. $4 \mathrm{~b}$; light blue crosses). Relative to present-day, these slopes in Eocene Polar Regions can be reduced because of the lack of sea ice during the Eocene, which would otherwise prevent the influence of a local source (Noone and Simmonds, 2004). This effect is probably most important in the Antarctic region, explaining in part the smaller increase in slope for Antarctica.

Despite obvious caveats related to both proxy-based reconstructions of SST and precipitation $\delta \mathrm{D}$, connecting these independent datasets with a model evaluation shows that they are mutually consistent. This provides independent support for the long-proposed reduced meridional temperature gradient during the Early/Middle Eocene.

\section{Conclusion}

We have shown that the integrated climate-isotope model (isoCAM3) is able to simulate the distribution of $\delta D$ values in precipitation on a global scale for both the present-day and Early/ Middle Eocene. The Eocene simulation, with an enforced reduced equator-to-pole temperature gradient, confirms the occurrence of enhanced moisture transport resulting in increased precipitation at high latitudes under low gradient conditions. We demonstrate that the isotopic composition of vapor and precipitation is heavily influenced by the imposed meridional temperature gradient, with $\delta \mathrm{D}$ values being appreciably more isotopically enriched in the Eocene, ranging between 0 and $-140 \%$ compared to 0 and $-300 \%$ o in the modern day. Furthermore, Eocene model results are broadly consistent with new $n$-alkane inferred precipitation $\delta \mathrm{D}$ and a compilation of $\delta \mathrm{D}$ and $\delta^{18} \mathrm{O}$ estimates from a suite of different proxies. The overall good correlation between our model results, using a reduced equatorto-pole temperature gradient, and annual mean temperature and precipitation proxy records independently confirms the earlier $\mathrm{TEX}_{86^{-}}$ based reconstructions of reduced Early/Middle Eocene latitudinal temperature gradients. Knowledge of how SST gradients have changed over time is thus central to understanding global patterns of isotopes in precipitation.

\section{Acknowledgements}

We acknowledge Virginia Tech Advanced Research Computing and the Department of Geosciences for computation support and resources. Model runs were also sponsored by the Stichting Nationale Computerfaciliteiten (National Computing Facilities Foundation, NCF) for the use of supercomputer facilities, with financial support from the Nederlandse Organisatie voor Wetenschappelijk Onderzoek (Netherlands Organisation for Scientific Research, NWO). General project funding was provided by the Darwin Centre for Biogeosciences and Utrecht University. Additional financial support came from Statoil. Huber acknowledges support from the National Science Foundation funding via P2C2 0902882-OCE, and von der Heydt personal support through a VENI grant by the Netherlands Organization for Scientific Research (NWO). This research used samples and 
data provided by the Integrated Ocean Drilling Program (IODP). Authors thank C. Heilmann-Claussen for providing samples from Denmark, C. Agnini for sending the samples from Italy, and Mark Pagani's lab at Yale University for assistance with compound specific $\delta \mathrm{D}$ measurements. We thank 4 anonymous reviewers for their constructive comments.

\section{References}

Abruzzese, M.J., Waldbauer, J.R., Chamberlain, C.P., 2005. Oxygen and hydrogen isotope ratios in freshwater chert as indicators of ancient climate and hydrologic regime. Geochim. Cosmochim. Acta 69 (6), 1377-1390.

Agnini, C., Muttoni, G., Kent, D.V., Rio, D., 2006. Eocene biostratigraphy and magnetic stratigraphy from Possagno, Italy: the calcareous nannofossil response to climate variability. EPSL 241, 815-830.

Andreasson, F.P., Schmitz, B., 2000. Temperature seasonality in the early middle Eocene North Atlantic region: evidence from stable isotope profiles of marine gastropod shells. GSA Bull. 112 (4), 628-640.

Barron, E.J., Fawcett, P.J., Peterson, W.H., Pollard, D., Thompson, S.L., 1995. A "simulation" of mid-Cretaceous climate. Paleoceanography 10, 953.

Basinger, J.F., 1991. The fossil forests of the Buchanan Lake Formation (Early Tertiary), Axel Heiberg Island, Canadian Arctic Archipelago: preliminary floristics and paleoclimate. Geol. Surv. Can. Bull. 403, 39-65.

Basinger, J.F., Greenwood, D.R., Sweda, T., 1994. Early Tertiary vegetation of Arctic Canada and its relevance to paleoclimatic interpretation. In: Boulter, M.C. (Ed.), Arctic Plants AND Climates: 65 Million Years of Change. Springer-Verlag, Berlin.

Bonan, G.B., Oleson, K.W., Vertenstein, M., Levis, S., Zeng, X.B., Dai, Y.J., Dickinson, R.E., Yang, Z.L., 2002. The land surface climatology of the community land model coupled to the NCAR community climate model. J. Climate 15, 3123-3149.

Brinkhuis, H., Schouten, S., Collinson, M.E., Sluijs, A., Sinninghe Damsté, J.S., Dickens, G.R., Huber, M., Cronin, T.M., Onodera, J., Takahashi, K., Bujak, J.P., Stein, R., van der Burgh, J., Eldrett, J.S., Harding, I.C., Lotter, A.F., Sangiorgi, F., van Konijnenburg-van Cittert, H., de Leeuw, J.W. Matthiessen, J., Backman, J., Moran, K., and the Expedition 302 Scientists, 2006. Episodic fresh surface waters in the Eocene Arctic Ocean. Nature 441, 606-609.

Caballero, R., Langen, P.L., 2005. The dynamic range of poleward energy transport in an atmospheric general circulation model. Geophys. Res. Lett. 32, L02705. doi:10.1029/2004GL021581.

Collins, W.D., Rasch, P.J., Boville, B.A., Hack, J.J., McCaa, J.R., Williamson, D.L., Briegleb, B., Bitz, C.M., Lin, S.J., Zhang, M.H., 2006. The formulation and atmospheric simulation of the Community Atmosphere Model version 3 (CAM3). J. Climate 19, 2144-2161.

Craig, H., 1961. Isotopic variations in meteoric waters. Science 133, 1702-1703.

Craig, H., Gordon, L.I., 1965. Deuterium and oxygen 18 variations in the ocean and the marine atmosphere. In: Tongiorgi, E. (Ed.), Stable isotopes in oceanographic studies and paleotemperatures. Lab. di Geol. Nucl, Pisa, Italy, pp. 9-130.

Crowley, T.J., Zachos, J.C., 2000. Comparison of zonal temperature profiles for past warm time periods. In: Huber, B.T., MacLeod, K.G., Wing, S.L. (Eds.), Warm Climates in Earth History. Cambridge University Press.

Dansgaard, W., 1964. Stable isotopes in precipitation. Tellus XVI, 436-468.

Eldrett, J.S., Greenwood, D.R., Harding, I.C., Huber, M., 2009. Increased seasonality through the Eocene to Oligocene transition in Northern high latitudes. Nature 459, 969-974 doi: 10.1038 .

Feng, X.H., Epstein, S., 1995. Climatic temperature records in dD data from tree-rings. Geochim. Cosmochim. Acta 59 (14), 3029-3037.

Frankenberg, C., Yoshimura, K., Warneke, T., Aben, I., Butz, A., Deutscher, N., Griffith, D. Hase, F., Notholt, J., Schneider, M., Schrijver, H., Röckmann, T., 2009. Dynamic processes governing lower-tropospheric $\mathrm{HDO} / \mathrm{H} 2 \mathrm{O}$ ratios as observed from space and ground. Science 325, 1374

Fricke, H.C., 2003. Investigation of early Eocene water-vapor transport and paleoelevation using oxygen isotope data from geographically widespread mammal remains. Geol. Soc. Am. Bull. 115, 1088-1096.

Greenwood, D.R., Wing, S.L., 1995. Eocene continental climates and latitudinal temperature gradients. Geology 23, 1044-1048.

Greenwood, D.R., Archibald, S.B., Mathewes, R.W., Moss, P.T., 2005. Fossil biotas from the Okanagan Highlands, southern British Columbia and northeastern Washington State: climates and ecosystems across an Eocene landscape. Can. J. Earth Sci. 42, 167-185. doi:10.1139/E04-100

Heilmann-Clausen, C., Nielsen, O.B., Gersner, F., 1985. Lithostratigraphy and depositional environments in the Upper Paleocene and Eocene of Denmark. Bull. Geol. Soc. Denmark 33, 287-323.

Huber, M., Caballero, R., 2003. Eocene El Nino: evidence for robust tropical dynamics in the "hothouse". Science 299, 877-881.

Huber, M., Nof, D., 2006. The ocean circulation in the southern hemisphere and its climatic impacts in the Eocene. Palaeogeogr. Palaeoclimatol. Palaeoecol. 231, 9-28.

Huber, M., Sloan, L.C., 2000. Climatic responses to tropical sea surface temperature changes on a "greenhouse" earth. Paleoceanography 15 (4), 443-450.

Huber, M., Sloan, L., Shellito, C.J., 2003. Early Paleogene oceans and climate: a fully coupled modeling approach using the NCAR CCSM. In: Wing, S.L., Gingerich, P.D., Schmitz, B., Thomas, E. (Eds.), Causes and consequences of globally warm climates in the Early Paleogene, special paper-Geological Society of America. Geological Society of America, Boulder, Colorado, pp. 25-47.

IAEA/WMO, 2006. Global network of isotopes in precipitation. The GNIP Database. Accessible at: http://www.isohis.iaea.org
Ingraham, N.L., 1998. Isotopic variation in precipitation. In: Kendall, C., McDonnell, J.J. (Eds.), Isotope Tracers in Catchment Hydrology. Elsevier, New York, pp. 87-118.

Jacobs, B.F., Herendeen, P.S., 2004. Eocene dry climate and woodland vegetation in tropical Africa reconstructed from fossil leaves in northern Tanzania. Palaeogeogr. Palaeoclimatol. Palaeoecol. 213, 115-123.

Jahren, A.H., Sternberg, L.S.L., 2003. Humidity estimate for the middle Eocene Arctic rain forest. Geology 31, 463-466.

Jahren, A.H., Byrne, M.C., Graham, H.V., Sternberg, L.S.L., Summons, R.E., 2009. The environmental water of the middle Eocene Arctic: evidence from $\delta \mathrm{D}, \delta^{18} \mathrm{O}$ and $\delta^{13} \mathrm{C}$ within specific compounds. Palaeogeogr. Palaeoclimatol. Palaeoecol. 271, 96-103.

Joussaume, S., Sadourny, R., Jouzel, J., 1984. A general circulation model of water isotope cycles in the atmosphere. Nature 311, 24-29.

Jouzel, J., Koster, R.D., Suozzo, R.J., Russell, G.L., White, J.W.C., Broecker, W.S., 1987 Simulation of the HDO and $\mathrm{H} 2180$ atmospheric cycles using the NASA GISS general circulation model: The seasonal cycle for present-day conditions. J. Geophys. Res. 92 (14), 739-14 760.

Lee, J.-E., Fung, I., DePaolo, D.J., Henning, C.C., 2007. Analysis of the global distribution of water isotopes using the NCAR atmospheric general circulation model. J. Geophys. Res. 112, D16306. doi:10.1029/2006JD007657.

Liu, W., Yang, H., Liwu, L., 2006. Hydrogen isotopic composition of $n$-alkanes from terrestrial plants correlate with their ecological life forms. Oceologia 150, 330-338.

Manabe, S., 1997. Early development in the study of greenhouse warming: the emergence of climate models. Ambio 26 (1), 47-51.

Markwick, P.J., 1994. "Equability", continentality, and Tertiary "climate": The crocodilian perspective. Geology 22, 613-616.

Masson-Delmotte, V., Shugui, H., Ekaykin, A., Jouzel, J., Aristarain, A., Bernardo, R.T., Bromwhich, D., Cattani, O., Delmotte, M., Falourd, S., Frezzotti, M., Galle, H., Genoni, L., Landais, A., Helsen, M., Hoffmann, G., Lopez, J., Morgan, V., Motoyama, H., Noone, D., Oerter, H., Petit, J.R., Royer, A., Ruemura, R., Schmidt, G., Schosser, E., Simaes, J., Steig, E., Stenni, B., Stievenard, M., Vimeux, F., White, J.W.C., 2008. A review of Antarctic surface snow isotopic composition: observations, atmospheric circulation and isotopic modelling. J. Climate 21 (13), 3359-3387.

Merlivat, L., Jouzel, J., 1979. Global climatic interpretation of the deuterium-oxygen 18 relationship for precipitation. J. Geophys. Res. 84, 5029-5033.

Mulch, A., Graham, S.A., Chamberlain, C.P., 2006. Hydrogen isotopes in Eocene river gravels and Paleoelevation of the Sierra Nevada. Science 313, 87-89.

Mulch, A., Teyssier, C., Cosca, M.A., Chamberlain, C.P., 2007. Stable isotope palaeoaltimetry of Eocene core complexes in the North American Cordillera. Tectonics 26 TC4001.

Noone, D., 2003. Water isotopes in CCSM for studying water cycles in the climate system. 8th Annual CCSM workshop, Breckenridge, Colorado, June 2003.

Noone, D., 2008. The influence of midlatitude and tropical overturning circulation on the isotopic composition of atmospheric water vapor and Antarctic precipitation. J. Geophys. Res. 113, D04102. doi:10.1029/2007JD008892.

Noone, D., Simmonds, I., 2002. Associations between d180 of water and climate parameters in a simulation of atmospheric circulation for 1979-95. J. Climate 15, 3150-3169.

Noone, D., Simmonds, I., 2004. The sea ice control on water isotope transport to Antarctica and implications for ice core interpretation. J. Geophys. Res. 109, D07105, doi:10.1029/2003JD004228.

Noone, D., Sturm, C., 2010. Comprehensive dynamical models of global and regional water isotope distributions. In: West, J., Bowen, G., Dawson, T., Tu, K. (Eds.), Isoscapes: Understanding Movement, Patterns, and Process on EARTH through Isotope Mapping. Springer, pp. 195-219.

Norris, R.D., Jones, L.S., Corfield, R.M., Cartlidge, J.E., 1996. Skiing in the Eocene Uinta mountains? Isotopic evidence in the Green river formation for snow melt and large mountains. Geology 24, 403-406.

Oleson, K.W., Dai, Y., Bonan, G., Bosilovich, M., Dickinson, R., Dirmeyer, P., Hoffman, F., Houser, P., Levis, S., Niu, G.Y., Thornton, P., Vertenstein, M., Yang, Z.L., Zeng, X., 2004. Technical description of the Community Land Model (CLM), NCAR/TN-461 + STR. 186 pp.

Pagani, M., Pedentchouk, N., Huber, M., Sluijs, A., Schouten, S., Brinkhuis, H., Sinninghe Damste, J.S., Dickens, G.R., and the Expedition 302 Scientists, 2006. Arctic hydrology during global warming at the Palaeocene/Eocene thermal maximum. Nature 442, 671-675.

Pearson, P.N., Palmer, M.R., 2000. Atmospheric carbon dioxide concentrations over the past 60 million years. Nature 406, 695-699.

Pearson, P.N., van Dongen, B.E., Nicholas, C.J., Pancost, R.D., Schouten, S., Singano, J.M., Wade, B.S., 2007. Stable warm tropical climate through the Eocene Epoch. Geology 35 (3), 211-214.

Risi, C., Bony, S., Vimeux, F., 2008. Influence of convective processes on the isotopic composition $\left(\delta^{18} \mathrm{O}\right.$ and $\left.\delta \mathrm{D}\right)$ of precipitation and water vapor in the tropics: 2 Physical interpretation of the amount effect. J. Geophys. Res. 113, D19306. doi:10.1029/2008JD009943.

Sachse, D., Radke, J., Gleixner, G., 2004. Hydrogen isotope ratios of recent lacustrine sedimentary $n$-alkanes record modern climate variability. Geochim. Cosmochim. Acta 68 (23), 4877-4889.

Sachse, D., Radke, J., Gleixner, G., 2006. $\delta$ D values of individual $n$-alkanes from terrestrial plants along a climatic gradient - implications for the sedimentary biomarker record. Org. Geochem. 37, 469-483.

Schmidt, G.A., Bigg, G.R., Rohling, E.J., 1999. Global seawater oxygen-18 database http://www.data.giss.nasa.gov/o18data/1999.

Schmidt, G.A., Hoffmann, G., Shindell, D.T., Hu, Y., 2005. Modeling atmospheric stable water isotopes and the potential for constraining cloud processes and stratosphere-troposphere water exchange. J. Geophys. Res. 110, D21314. doi:10.1029/2005JD005790.

Schouten, S., Hopmans, E.C., Schefuß, E., Sinninghe Damsté, J.S., 2002. Distributional variations in marine crenarchaeotal membrane lipids: a new tool for reconstructing ancient sea water temperatures? Earth Planet. Sci. Lett. 204, 265-274. 
Schouten, S., Hopmans, E.C., Forster, A., van Breugel, Y., Kuypers, M.M.M., Sinninghe Dampsté, J.S., 2003. Extremely high sea surface temperatures at low latitudes during the middle Cretaceous as revealed by archaeal membrane lipids. Geology 31, 1069-1072.

Sessions, A.L., Burgoyne, T.W., Schimmelmann, A., Hayes, J.M., 1999. Fractionation of hydrogen isotopes in lipid biosynthesis. Org. Geochem. 30 (9), 1193-1200.

Sewall, J.O., Sloan, L.C., Huber, M., Wing, S., 2000. Climate sensitivity to changes in land surface characteristics. Glob. Planet. Change 26 (4), 445-465.

Shellito, C.J., Sloan, L.C., Huber, M., 2003. Climate model sensitivity to atmospheric CO2 levels in the Early-Middle Paleogene. Palaeogeogr. Palaeoclimatol. Palaeoecol. 193 (1), 113-123.

Sloan, L.C., 1994. Equable climates during the early Eocene- significance of regional paleogeography for North-American climate. Geology 22 (10), 881-884.

Sloan, L.C., Barron, E.J., 1992. A comparison of Eocene climate model results to quantified paleoclimate interpretations. Palaeogeogr. Palaeoclimatol. Palaeoecol. 93, 183-202.

Sloan, L.C., Huber, M., Crowley, T.J., Sewall, J.O., Baum, S., 2001. Effect of sea surface temperature configuration on model simulations of "equable" climate in the Early Eocene. Palaeogeogr. Palaeoclimatol. Palaeoecol. 167, 321-335.

Sluijs, A., Röhl, U., Schouten, S., Brumsack, H.-J., Sangiorgi, F., Sinninghe Damsté, J.S., Brinkhuis, H., 2008. Arctic late Paleocene-early Eocene paleoenvironments with special emphasis on the Paleocene-Eocene thermal maximum (Lomonosov Ridge, Integrated Ocean Drilling Program Expedition 302). Paleoceanography 23. doi:10.1029/2007PA001495

Speelman, E.N., Reichart, G.J., de Leew, J.M., Rijpstra, W.I.C., Sinninghe Damsté, J.S. 2009a. Biomarker lipids of the freshwater fern Azolla and its fossil counterpart from the Eocene Arctic Ocean. Org. Geochem. 40, 628-637.
Speelman, E.N., van Kempen, M.M.L., Barke, J., Brinkhuis, H., Reichart, G.J., Smolders, A.J.P., Roelofs, J.G.M., Sangiorgi, F., de Leeuw, J.W., Lotter, A.F., Sinninghe Damsté, J.S., 2009b. The Eocene Arctic Azolla bloom: environmental conditions, productivity and carbon drawdown. Geobiology 7, 155-170.

Wilf, P., Wing, S.L., Greenwood, D.R., Greenwood, C.L., 1998. Using fossil leaves as paleoprecipitation indicators: an Eocene example. Geology 26 (3), 203-206.

Wing, S.L., Greenwood, D.R., 1993. Fossils and fossil climate: the case for equable continental interiors in the Eocene. Philos. Trans. R. Soc. Lond. B 341, 243-252.

Wolfe, J.A., 1994. Tertiary climatic changes at middle latitudes of western North America. Palaeogeogr. Palaeoclimatol. Palaeoecol. 108, 195-205.

Worden, J., Noone, D., Bowman, K., 2007. Importance of rain evaporation and continental convection in the tropical water cycle. Nature 445, 528-532.

Yang, H., Pagani, M., Briggs, D.E.G., Equiza, M.A., Jagels, R., Leng, Q., LePage, B.A., 2009. Carbon and hydrogen isotope fractionation under continuous light: implications for paleoenvironmental interpretations of the High Arctic during Paleogene warming. Oecologia 160, 461-470. doi:10.1007/s00442-009-1321-1.

Yao, Y.-F., Bera, S., Ferguson, D.K., Mosbrugger, V., Paudayal, K.N., Jin, J.-H., Li, C.-S., 2009. Reconstruction of paleovegetatin and paleoclimate in the Early and Middle Eocene, Hainan Island, China. Clim. Change 92, 169-189.

Zachos, J.C., Lohmann, K.C., Walker, J.C.G., Wise, S.W., 1993. Abrupt climate change and transient climates in the Paleogene: a marine perspective. J. Geol. 101, 193-215.

Zachos, J.M., Scott, L.D., Lohmann, K.C., 1994. Evolution of early Cenozoic marine temperatures. Paleoceanography 9 (2), 353-387.

Zachos, J.M., Dickens, G.R., Zeebe, R., 2008. An early Cenozoic perspective on greenhouse warming and carbon-cycle dynamics. Nature 451, 279-283. 